\title{
Cinema indígena: de objeto a sujeito da produção cinematográfica no Brasil
}

\author{
Karliane Macedo Nunes
}

Universidade Federal do Amazonas; Parintins-AM, Brasil. Email: karliane77@yahoo.com.br

\section{Renato Izidoro da Silva}

Universidade Federal do Amazonas; Parintins-AM, Brasil.

Email: izidoro.renato@gmail.com

\section{José de Oliveira dos Santos Silva}

Organização dos Professores Indígenas Sateré-Mawé, Parintins-AM, Brasil.

Email: josesatere@yahoo.com.br

Resumo: Baseado nos Estudos Culturais, o presente artigo reflete sobre uma experiência de produção cinematográfica junto a um grupo de jovens da etnia Sateré-Mawé, habitante da Amazônia brasileira. Localizamos a experiência em um contexto histórico e político mais amplo do Cinema Indígena. Abordamos as principais características do Cinema Brasileiro no decorrer do século XX e sua relação com movimentos nacionalistas na construção da imagem do índio. Focamos o Cinema Novo como uma ruptura com os padrões hollywoodianos da indústria cinematográfica brasileira da época a partir do neorrealismo italiano e da Nouvelle Vague francesa, na hipótese historiográfica e epistemológica de preparação de uma base ideológica e metodológica para a emergência futura do Cinema Indígena. Não perdemos de vista o Cinema e o Cinema Indígena nas Américas, principalmente em face das problemáticas relativas à identidade nacional no bojo das políticas culturais dos Estados nacionais que afetam diretamente a diversidade étnica em seus territórios. Com base nesse contexto, prosseguimos com uma compreensão do projeto "Cineastas Indígenas” da ONG "Vídeo nas Aldeias” enquanto um dispositivo teórico e metodológico a ser multiplicado e transformado. indígena.

Palavras-chave: Cinema nacional; estudos culturais; Sateré-Mawé; cinema

\section{Cine indígena: de objeto a sujeto de la producción cinematográfica en Brasil}

Resumen: En base a los estudios culturales, este artículo reflexiona sobre la experiencia de la producción de la película con un grupo de jóvenes de etnia SateréMawé, habitantes de la Amazonia brasileña. La experiencia se localiza en un contexto histórico y político más amplio del cine indígena. Se discuten las principales características del cine brasileño en el siglo XX y su relación con los movimientos nacionalistas en la construcción de la imagen del indígena. Se centra en el Cinema 
Novo como una ruptura con los estándares de Hollywood de la industria cinematográfica brasileña en la época del neorrealismo italiano y de la Nouvelle Vague francesa, en la hipótesis historiográfica y epistemológica de preparación de una base ideológica y metodológica para la futura aparición del cine indígena. No se pierde de vista el cine y el cine indígena en el continente americano, principalmente de cara a los problemas de la identidad nacional, en medio de las políticas culturales de los Estados nacionales que afectan directamente a la diversidad étnica en sus territorios. Sobre la base de este marco, se procede a una comprensión del proyecto "Cineastas Indígenas" de la ONG "Video en las Aldeas” como un dispositivo teórico y metodológico a ser multiplicado y transformado. cine indígena.

Palabras clave: Cine Nacional; estudios culturales; Sateré-Mawé;

\title{
Indigenous cinema: From object to subject of film production in Brazil
}

\begin{abstract}
Based on cultural studies, this article refers to a cinematographic production experienced by a group of Sateré Mawé youngsters, inhabitants of the brazilian Amazon. We tried to set this experience in a broader historical and political context of indigenous cinema. We discuss the main features corcerning brazilian cinema during the twentieth century and its relationship to nationalist movements in the building of indigenous people image. We focused on Cinema Novo as a break with Hollywood standards, working with the assumption of it as an ideological and epistemological basis for the future emergence of Indigenous Cinema. We specially emphasized the indigenous cinema on America, concerning to questions related to national identity, within culture politics of the national States which directly affect ethnic diversity in their territories. In this context, we discuss the "Cineastas Indígenas" project, realized by the NGO "Video nas Aldeias" as an important theoretical and methodological tool, that must be transformed and multiplyed.
\end{abstract}

Key words: National cinema; cultural studies; Sateré-Mawé; indigenous cinema.

$* * *$

\section{Introdução $^{1}$}

Componente cultural contemporâneo, o cinema constitui importante corpus de pesquisas e ações de diferentes áreas, com destaque para os chamados Estudos Culturais, que privilegiam sua "disseminação na cultura por meio de um amplo contínuo discursivo, no qual os textos são inseridos em uma matriz social e produzem consequências em todo mundo" (Stam 2003: 250). Interessa-se por todos os tipos de texto e não apenas por aqueles considerados eruditos e, com isso, buscam demarcar tanto os momentos de manipulação hegemônica quanto de resistência ideológica (Ibid.). 
Os Estudos Culturais operam no sentido de abrir espaços para vozes marginalizadas e grupos sub-representados, a partir de pesquisas que incluem análises de representações hegemônicas e de minorias, local de inscrição desta proposta, que situa o cinema no espectro mais amplo das práticas culturais, considerando-o enquanto sistema de representação e significação, de onde se expressam várias vozes sociais e diferentes perspectivas culturais, políticas e econômicas. Se for através da elaboração de narrativas que a cultura produz e reproduz seus significados, então o cinema constitui-se numa poderosa ferramenta de circulação de ideologias e de construção de identidades, tendo como fundamento material as dinâmicas culturais, políticas e econômicas atualmente globalizadas.

Apreendemos os Estudos Culturais como um referencial teóricometodológico contemporaneamente adequado para orientar tanto práticas quanto reflexões críticas e transformadoras acerca das produções cinematográficas cujo escopo consiste em representações individualizadas ou coletivas de indígenas no Brasil e no mundo. Isso se deve à hipótese os povos nativos vivenciam as problemáticas da modernização, tema-chave para Estudos Culturais, iniciada pelas políticas coloniais expansionistas da Europa dos seiscentos, sendo, século a século, re-atualizadas por novas teorias sociais, técnicas e tecnologias, além de orientadas por interesses econômicos do desenvolvimento capitalista global.

As representações cinematográficas de indígenas vêm se configurando como fenômeno moderno e global crescente desde o início do século XX até o atual momento do século XXI segundo, respectivamente, dois básicos momentos e modos históricos: a) a temática indígena abordada por cineastas não indígenas; b) a temática indígena produzida por cineastas indígenas. O primeiro momento, predominante durante o século $\mathrm{XX}$, faz parte de um contexto hegemônico relacionado às produções cinematográficas nacionalistas e imperialistas como um dos mecanismos políticosculturais dos Estados e suas elite para a continuação do processo global de colonização.

O segundo momento, como uma marca do século XXI; apresenta um modo possivelmente contra-hegemônico de proceder com as representações cinematográficas acerca de temáticas indígenas. Seu caráter principal está no fato de os processos produtivos não mais estarem majoritariamente nas mãos de cineastas não indígenas. Por iniciativa de alguns desses, em todo mundo, alguns indígenas ou aborígenes ${ }^{2}$ foram iniciados na arte e na indústria do cinema no âmbito de suas questões nacionais e globais; especialmente por meio do ensino-aprendizagem de técnicas de manipulação de câmeras, de direção, de elaboração de roteiros e de edição de vídeos. Esse tipo de formação vem possibilitando a emergência de uma cinematografia indígena diferente a partir de mudanças sobre temas, narrativas, personagens, atores no âmbito das problemáticas indígenas na Modernidade.

Considerando o segundo momento um marco na história cultural do Ocidente, especialmente na história dos povos indígenas e na do cinema 
mundial e, particularmente, brasileiro, o presente trabalho consiste em uma modesta parte deste marco, conforme recorte étnico, social, temporal, geográfico e econômico no âmbito de um projeto de extensão universitária junto a alguns jovens Sateré-Mawé que vivem em uma pequena comunidade urbana, chamada Casa de Trânsito, localizada na cidade de Parintins, estado do Amazonas, Brasil. Basicamente, o mencionado projeto implicou um trabalho de formação técnica, tecnológica e antropológica dirigida aos jovens comunitários no campo da produção cinematográfica, a fim de que esses fizessem parte desse importante momento de reflexão crítica e transformadora em torno das representações indígenas no Brasil, na América e no mundo.

Para tanto, o presente texto descreverá de maneira crítica e reflexiva algumas problemáticas centrais relativas à representação do índio no cinema brasileiro, sendo que, na sequencia, mediante uma perspectiva não detalhada, localizaremos suas produções no contexto americano. Apresentaremos uma síntese dos momentos constituintes da experiência de ensino-aprendizagem acerca das técnicas, tecnologias e reflexões antropológicas junto aos jovens indígenas Sateré-Mawé que originou este trabalho escrito. Por fim, abordaremos a problemática entre as perspectivas e interesses teóricos, práticos e críticos em torno das questões políticas, culturais e sociais da identidade indígena expressos pelos aprendizes SateréMawé e aqueles pontos de vista responsáveis por fundamentar e orientar teórica e metodologicamente nossa proposta segundo os Estudos Culturais.

\section{O cinema nacional brasileiro e os limites do estrangeiro e do cultural: uma história anterior ao Cinema Indígena}

O cinema nacional brasileiro aborda a temática indígena desde a sua origem, em 1910. Desde então vem contribuindo para a construção de uma imagem dos grupos e sujeitos indígenas que situa-nos em termos de bons e maus selvagens face aos preceitos conceituais como civilização, nacional e Estado. Essas narrativas, em sua maioria, partem de um ponto de vista dominante etnocêntrico e universalista que, por meio da fixação de estereótipos, difundiram e continuam a difundir representações que situam os povos indígenas brasileiros no passado histórico, destituindo-lhes de particularidades individuais e coletivas e caracterizando-lhes como primitivos, selvagens, ingênuos, infantis, preguiçosos, exóticos, entre outros, ainda que haja momentos de exceção (Cunha 2000).

Almeida (2010) explica que a questão indígena no Brasil deve ser refletida a partir do processo de independência em relação a Portugal ao desembocar no desafio em se transformar uma colônia mestiça, cuja identidade nacional estava vinculada à sua metrópole, em Estado nação. Apesar da imagem da independência, “[...] a ideologia do novo Estado brasileiro baseava-se nos valores europeus de modernização, progresso e superioridade do [europeu]" (Ibid.: 135). Ideal hegemônico em nossa época: "Predominava a ideia de que uma nação deveria ser constituída de um 
território, um povo, uma língua, uma cultura e uma história”. Contudo, em se tratando de países coloniais Americanos, Africanos e Asiáticos, surge a seguinte pergunta acerca das contradições entre as bases materiais e a ideologia dominante referente ao nacionalismo dos Estados no século XIX: "Como construir uma nação e uma história de branco a partir de uma realidade repleta de índios e negros?” (Ibid.: 135).

Segundo Shohat e Stam (2006: 399): “Qualquer discussão séria sobre o cinema no Terceiro Mundo deve examinar a questão complexa do 'nacional'”. Diferentes são as questões básicas do cinema no Primeiro Mundo, onde o nacional estaria fixado em oposição à problemática do multiculturalismo ou multinacionalismo terceiro-mundista; que além de suas nações indígenas e afrodescendentes, contam com comunidades japonesas, italianas e alemãs, por exemplo, que também orientam políticas locais em torno das próprias línguas e culturas. De modo enfático, os mesmos autores asseveram que "todo filme é produto de uma indústria nacional, é falado em uma língua nacional, retrata situações nacionais e recicla intertextos nacionais. [...] seja um filme mitológico hindu, um melodrama mexicano ou um épico terceiro-mundista, projeta um imaginário nacional” (Ibid.: 399).

Sobre o início da teoria do cinema, “[...] a história do cinema [...] deve ser considerada à luz do crescimento do nacionalismo, para o qual o cinema se transformou em um instrumento estratégico de ‘projeção' dos imaginários nacionais” (Stam 2003: 33),. Considerando a genealogia dos nacionalismos como uma luta contra a diversidade cultural autóctone, diaspórica e/ou imigrante, o cinema deve ser estudado em suas relações com o colonialismo imperialista: “[...] processo pelo qual as potências europeias conquistaram [...] hegemonia econômica, militar, política e cultural em grande parte da Ásia, da África e das Américas” (Ibid.: 33). Sobre essas regiões, as potências econômicas e políticas mundiais construíram um monopólio da produção, da distribuição e da exibição cinematográfica.

Não foi por acaso que os maiores produtores do cinema mudo (GrãBretanha, França, Estados Unidos e Alemanha), entre final dos oitocentos e início dos novecentos, foram também os Estados Nações que maior poder imperial possuíam e ainda possuem. Toda a filmografia dos primórdios do cinema teve como visada enaltecer interna e externamente o empreendimento europeu e norte-americano acerca da continuação do processo colonizador global sobre os povos originários. A projeção imaginária idealizou maciçamente a empresa colonial como missão civilizatória filantrópica motivada pelo desejo de avançar sobre as fronteiras da ignorância, da tirania e da doença enquanto representações negativas das colônias que justificavam o aperto do cerco imperialista no Terceiro Mundo (Ibid.).

O curioso e aparentemente paradoxal desse contexto é que para tratarmos do cinema nacional brasileiro temos que considerar o nacionalismo colonial e imperial de países de Primeiro Mundo. Por quê? Nossa hipótese é a de que os nacionalismos terceiro-mundistas não passaram de mecanismos intensivos e ostensivos do colonialismo imperial estrangeiro, enquanto 
processo colonial interno recaído sobre as nações primeiras e as assimiladas, de tal modo que em estados como o Brasil existem vários países e nações em seu interior federal, estadual e local; tal como expressa o senso comum corrente (Shohat e Stam 2006). Queremos dizer com isso que todo nacionalismo é, em grande parte, um colonialismo estrangeiro disfarçado; na medida em que sua efetivação depende de agentes imperialistas do próprio local ou instalados nele, procedimento característico, por exemplo, das ditaduras Latino Americanas financiadas pelos EUA e Europa. “As nações-estado das Américas, da África e da Ásia [...] muitas vezes ‘encobrem’ a existência de povos nativos em seus territórios”; isso por que "os terceiro-mundistas muitas vezes forjaram sua ideia de nação de acordo com o modelo europeu, nesse sentido obedecendo à narrativa iluminista do eurocentrismo” (Ibid.: 402).

Desse modo, nas palavras de Stam (2003: 35): “O objeto da teoria do cinema -os filmes propriamente ditos-é profundamente internacional por natureza”. Não obstante, é sempre paradoxal ou contraditoriamente que tratamos do Cinema Nacional em oposição Cinema Internacional ou Estrangeiro. A nosso ver, o disfarce cinematográfico do imperialismo internacional dos países de Primeiro Mundo no interior das regiões colonizadas começa com o fato de que antes das distribuições de filmes estrangeiros invadirem massivamente outros solos nacionais, a produção fílmica -em termos técnicos, tecnológicos e ideológicos- se disseminou pelo mundo em diversos locais concomitantemente em diversos países de Terceiro Mundo. Stam (2003: 36) ensina que “a bela época cinematográfica brasileira [...] ocorreu entre 1908 e 1911, antes de o país ser invadido pelas companhias de distribuição norte-americanas logo depois da Primeira Guerra Mundial”. Não por acaso, que nessa mesma época a imagem do indígena já fora representada no cinema.

Essa rápida e ostensiva disseminação pode ser explicada ao considerarmos que as técnicas, as tecnologias e as ideologias, isto é, o conhecimento em sua estrutura informacional, possui melhores condições imateriais, devido à natureza virtual do conhecimento, de serem disseminados, ao compararmos com a circulação de produtos materialmente físicos como é o caso dos rolos de películas propriamente ditos. Nesse sentido, o curioso e o paradoxal desse fenômeno de disseminação mundial da produção cinematográfica teve início com pessoas simpatizantes e disponíveis para incorporar ou se aculturar a partir dos conhecimentos técnicos, tecnológicos e ideológicos do cinema europeu e posteriormente o americano. Por esse motivo, podemos justificar o fato de os filmes nacionais expressarem por longas décadas a ideologia e a estética europeia e norteamericana, a começar pelas representações estereotipadas e descontextualizadas do índio no Brasil.

A hipótese difundida tem maior expressão em contextos dos governos ditatoriais na América Latina, em particular no Brasil. Autran (2003) explica, por exemplo, que tanto durante a ditadura quanto a “democracia” Vargas no Brasil, que integram os anos de 1930 a 1945 e de 1951 a 1954, respectivamente, foi empreendida uma luta governamental contra o documentário realista 
em curta metragem, para aplicá-lo propagandas do governo acerca do país enquanto nação imaginada a partir de padrões militares, eugênicos e higiênicos provindos da Europa; com negação explícita das culturas indígenas e afrodescendentes. Outros exemplos são duas principais indústrias cinematográficas entre as décadas de cinquenta e sessenta: a) Vera Cruz (São Paulo, 1950-1954, com 22 filmes); e b) Atlântida (Rio de Janeiro, 19411962, com 66 filmes).

A primeira, considerada a “Hollywood dos Trópicos”, responsável por produzir filmes que retratassem o desenvolvimentismo e o nacionalismo industrial brasileiro, tendo como cenário a cidade São Paulo. Já a segunda, também segundo padrões norte-americanos, produziam comédias e musicais, as chanchadas, em que a cultura popular brasileira aparecia de maneira estereotipada com base na figura do malandro, do boêmio e da suposta sexualidade exacerbada da mulher brasileira (Malafaia 2008). Não podemos esquecer que esse estereótipo do brasileiro era e ainda é justificado como característica essencial da mestiçagem do branco com o índio e com o negro. Assim, a sexualidade feminina das chanchadas e, posteriormente, dos pornôs chanchadas, tem como fundamento a suposta e imaginária libertinagem sexual das índias e das negras africanas. A malandragem masculina segue mesma lógica.

A questão do estrangeirismo ideológico no cinema brasileiro, sempre disfarçado de nacional, parece se consolidar por meio das infraestruturas técnicas (recursos humanos) e tecnológicas (equipamentos) de sua produção. Fruto da polêmica entre o nacional e o estrangeiro, a empresa Vera Cruz e outras; como a Maristela S. A. (São Paulo), sofreram inúmeras críticas nacionalistas devido à corrente contratação de técnicos estrangeiros para atender inúmeros setores da produção como roteiristas, montadores, ambientadores, cenógrafos, fotógrafos e diretores. Críticos como Alex Viany, um dos precursores do Cinema Novo, problematizou a possibilidade de as ideologias norte-americana e europeia estarem sendo implantadas a partir das bases culturais inerentes aos próprios recursos humanos atuantes na cinematografia brasileira; mesmo por que, por ser uma arte nascente, pensavam não ser provável a existência de brasileiros tecnicamente treinados para as necessidades das produções (Autran 2003). Isso pode justificar as vezes em que o índio foi representado por atores brancos maquiados.

Com o Golpe Militar, 1964, o cinema brasileiro sofre mudanças com a política da censura recaída sobre as películas do Cinema Novo, crítico da modernização desenvolvimentista e burguesa da sociedade brasileira e dos padrões cinematográficos hollywoodianos. A cinematografia brasileira não é freada, mas o governo militar opta por atuar no controle da distribuição, difusão e exibição das películas. Como bem fundamenta Turner (1997: 131): “As instituições cinematográficas têm interesses políticos que em última análise determinam quais os filmes que serão feitos, para não dizer os que serão vistos”. O regime militar orientou a ênfase de sua política para a segunda situação. Construindo significados capitalistas ao desenvolvimento econômico e cultural para o público, a indústria cinema- 
tográfica e a cultura no Brasil, a maioria dos filmes liberados era proveniente de Hollywood, sendo que as duas principais indústrias brasileiras de cinema haviam declinado.

Nem mesmo o Cinema Novo, crítico da perspectiva industrial e ficcional do cinema brasileiro pautado em conteúdos e formas estrangeiras, iniciada pela Atlântida e frustradamente fortalecida pela Vera Cruz, escapou da dicotomia nacional-estrangeiro em suas produções, tanto em termos ideológicos ou teóricos, quanto técnicos e tecnológicos. Diferentemente do que podemos imaginar pelo discurso nacional-popular cinemanovista, esse movimento brasileiro nasceu a partir do neorrealismo italiano e da Nouvelle Vague francesa, que já vinha motivando o cinema brasileiro independente das indústrias cinematográficas carioca e paulista (Carvalho 2006; Autran 2003).

Um paralelo entre o neorrealismo italiano e a Nouvelle Vague francesa, além de sua contemporaneidade em face do pós Segunda Guerra e, consequentemente, a coincidência das problemáticas sociais, o fato é que o contexto infraestrutural de então forçou transformações significativas na cinematografia europeia, em especial acerca de seus temas e de sua estética ou de seu formalismo. Basicamente, a crise econômica gerada pela guerra enfraqueceu as realizações cinematográficas de estúdio, as quais contavam com equipamentos cenográficos e de filmagem caros, além de seu comum elenco de atores já reconhecidos. Além disso, os próprios conteúdos ligados à noção benéfica e maravilhosa do desenvolvimento da Modernidade no sentido de se atingir o ápice da civilização já não faziam sentido após as catástrofes bélicas geradas pelas condições materiais e intelectuais da própria época (Stam 2003). Contra os capitalistas e os nazifascistas, o discurso intelectual comunista tomou a cena social e política no sentido das artes e das filosofias.

Embora mais tardiamente que as filosofias e as demais artes, o cinema reconheceu seu potencial de reconstrutor, reformador ou mesmo revolucionário às voltas dos ideais da velha sociedade moderna, agora questionada pelos efeitos da guerra por ela produzida. Sem recursos materiais e humanos especializados, cineastas italianos e franceses, ao lado de comunistas, passaram a produzir seus filmes à margem das antigas estruturas e infraestruturas cinematográficas até então vigentes em sua face industrial; só que agora sob a paulatina aproximação da sombra das tendências políticas de direita e de extrema direita dos regimes autoritários ligados à Igreja Católica e abertos ao cinema hollywoodiano. Sem a infraestrutura industrial e sem contar com as políticas de estado, os cineastas independentes produziram seus filmes nos espaços públicos das cidades, cujos atores e produtores eram pessoas do próprio cotidiano popular, o qual era o pano de frente temático das filmagens (Fabris 2006).

Nesse sentido, embora o Cinema Novo seja de inspiração europeia às voltas do pós-guerra, intensificando as tensões entre o nacional e o estrangeiro nas produções brasileiras, as fórmulas básicas do neorrealismo 
e da Nouvelle Vague não definem a forma e tampouco o conteúdo das produções, sendo, portanto, muito diferente da equação cinematográfica hollywoodiana influente no Brasil em termos industriais. O dispositivo intelectual "neoeuropeu" leva os cineastas e os intelectuais brasileiros e de outros países a mergulharem na profundidade e na superficialidade do cotidiano marcado pelas questões do nacional, do popular, do índio e do negro se opondo ao nacionalismo industrial burguês. Entra em cena a diversidade do povo. O momento era propício para a liberdade artística e intelectual no período entre a segunda metade da década de 1940 e a primeira metade da década de 1960 durante os governos presidenciais de Kubitschek e de Goulart, respectivamente.

Segundo Malafaia (2008: 203), "neste momento, o nacional-popular constituía-se na proposta político-cultural mais adequada à compreensão da nova realidade gerada pelo processo de modernização: tratava-se de difundir a necessidade de desenvolver economicamente a sociedade brasileira incluindo os setores populares até então colocados à margem desse processo". Com efeito, longe de ser um movimento genuinamente nacional, o Cinema Novo nasce em uma "[...] conjuntura internacional, um momento marcado pela descolonização e emergência dos países do chamado Terceiro Mundo, pela Revolução Cubana e pela Guerra Fria” (Idem.: 203). A proposta se desenrola com produções independentes sem as preocupações com acabamentos formais e programáticos da indústria que buscava condições ideais de filmagens. Com o Cinema Novo, os roteiros e as gravações estavam abertos ao acaso das condições materiais e ideológicas próprias do contexto de produção; de modo que as características técnicas, tecnológicas e ideológicas do próprio filme pudessem ser um reflexo realista de seu contexto histórico; em especial concernente às suas tensões sociais.

O movimento cinemanovista abre as portas para se pensar o nacionalismo de um ponto de vista popular, indígena e negro, isto é, da perspectiva das minorias em face de suas tensões com as classes dominantes econômica e politicamente. O Cinema Novo olhar através de lentes nacionalistas opostas aos nacionalismos europeu e norte-americano, antes e depois da Segunda Guerra, ambos extremamente influentes nas políticas do Estado brasileiro: "do ponto de vista da raça, classe, gênero e sexualidade, essas nações [Estado] em geral permanecem etnocêntricas, patriarcais, burguesas e homofóbicas" (Shohat e Stam 2006: 402). De acordo com Shohat e Stam (2006: 400), nos “[...] nacionalismos da América Latina, [...] o objetivo é a oposição ao poder hegemônico do Norte”. Não obstante, a oposição também recai aos seus poderes internos disfarçados de nacional por meio do discurso desenvolvimentista industrial e militar, esse último atrelado à noção de fronteiras geográficas; problemática em que o indígena é inserido tanto como subversivo quanto como protetor (Cunha 2012).

A partir dessas questões o cinema se insere em uma discussão filosófica e antropológica acerca da problemática e difícil definição do que pode vir a ser uma identidade nacional. Essa, com base em Ortiz (2006), ora 
pode estar vinculada à cultura popular ora às políticas culturais verticalizadas pelo Estado. O Cinema Novo “[...] procura encontrar na cultura popular os elementos que em princípio constituiriam o homem brasileiro” (Ibid.: 126127). Por conseguinte, "identidade nacional e cultura popular se associam aos movimentos políticos e intelectuais nos anos 1950 e 1960 e que se propõem redefinir a problemática brasileira em termos de oposição ao colonialismo” (Ibid.: PP). Vemos, portanto, que o chamado cinema nacional mundial, mas em particular no Brasil, é construído nessa tensão acerca da identidade nacional levantada pelos Estados-nação e pelos intelectuais vinculados ao popular. Agentes do colonialismo imperialista, os governos são um aparato de construção das hegemonias políticas, econômicas e culturais que buscam "[...] limitar ou controlar a multiplicidade de representações [incluindo as cinematográficas] mostrando algumas como marginais ou grosseiras [como é o caso das representações do índio no mundo]” (Turner 1997: 134).

Contudo, “[...] a pressão por hegemonia geralmente é enfrentada pela resistência da cultural popular 'não oficial' [lugar onde se insere, a nosso ver, o Cinema Novo e, também, a Mídia Indígena contemporânea]” (Ibid.). Não sendo uma genealogia direta entre o Cinema Novo e os Cineastas Indígenas, a intenção deste tópico sobre o cinema nacional brasileiro e suas fronteiras com os estrangeirismo foi chegar ao ponto das disputas cinematográficas em torno das representações da identidade nacional em que o índio no Brasil é peça-chave tanto do lado do Estado nação quanto do lado da proposta nacional-popular, isto é, de uma nacionalidade que surja do cotidiano, da filosofia, da arte e da mitologia das minorias. Categorizado como “Mídia Indígena” por Stam (2008), o uso de tecnologia audiovisual por indígenas atende a fins políticos e culturais contra hegemônicos. Esses fins foram preconizados pelo movimento antropofágico Modernista brasileiro de 1920. Tal movimento trás a noção do "bárbaro tecnicizado" como ideal artístico proposto pelo poeta Oswald de Andrade; fonte onde beberam os cinemanovistas de modo declarado (Stam 2003).

Agora, se iniciamos este tópico dizendo que o cinema terceiro mundista deve ser pensado às voltas da problemática complexa do nacional, o momento sugere que o cinema não pode ser discutido fora dos complexos culturais em qualquer parte do mundo, mas principalmente aqueles formados a partir da colonização dos territórios historicamente construídos como o caso dos países Latino Americanos, Africanos e Asiáticos. A questão do nacional é complexa porque a diversidade cultural existente no interior dos Estados modernos se tornou um problema para o conceito de identidade nacional. Foi nesses termos que Shohat e Stam (2006: 401) entenderam que o “[...] tópos de uma nação unitária disfarça as possíveis contradições entre os diferentes setores das sociedades do Terceiro Mundo”.

O índio no Brasil e em qualquer outro país em que eles existam vem se constituindo como uma das principais, senão a principal contradição histórica, filosófica e política para a consolidação ideológica e material da 
unidade identitária de um povo a ser confundido com o Estado-nação que o envolve. O Cinema Novo e a Mídia Indígena são exemplos de um descolamento dos meios de produção e das imagens construídas pelos governos sobre o povo e aquelas construídas por sujeitos do próprio povo conforme sua diversidade e particularidade étnica, econômica, política, geográfica, histórica etc.. Durante todo o século XX a imagem do índio foi produzida por não indígenas em sua maioria a serviço do Estado e da burguesia elitista e financiado por esses. Os resultados foram produções e difusões de imagens fantásticas ou deprimentes de um índio imaginário conforme interesses dos grupos hegemônicos. Não obstante, os Cineastas Indígenas vêm expressando representações do índio em que muitas vezes nos faz esquecer seu estatuto de nacionalizado e tutelado pelo Estadonação.

Excluída da indústria cinematográfica atual, a Mídia Indígena, de modo semelhante ao contexto de produção cinemanovista na década de 1950, horizontaliza e dilui a dicotomia cineasta e público, na medida em que “[...] os produtores são também os espectadores [...]. Embora [...] patrocinados por governos liberais ou grupos de apoio internacional, [...] têm pequena escala e baixo orçamento" (Shohat e Stam 2006: 70). A exclusão do contexto industrial hegemônico longe de ser um problema se torna a mola infraestrutural para se trabalhar temas e formas jamais propostas pelo cinema profissional e comercial. Com efeito, também distante de ser um problema apenas restrito ao cinema, a "[...] mídia indígena constitui veículo poderoso para comunidades que lutam contra a expulsão geográfica, a deterioração econômica e ecológica e o aniquilamento cultural” (Ibid.: PP). Nesse sentido, em tais produções os índios "[...] se apresentam não como primitivos ingênuos, mas como antagonistas ecológica e politicamente sofisticados da civilização imperialista” (Ibid: 473).

\section{O Cinema Indígena nas Américas: a questão do nacionalismo e da iniciativa não indígena}

Como pudemos estudar no tópico anterior, a definição de uma identidade nacional esbarra na problemática da origem, na medida em que a figura do genuíno é logo questionada por investigações históricas que consideram as interações culturais na formação de povos, comunidades, nações, países, sujeitos etc.. Verificamos, por conseguinte, que o nacionalismo de Estado não passa de uma versão disfarçada do eurocentrismo e do norte-americanismo colonialistas e imperialistas. Não obstante, as correntes nacionalistas contrárias às perspectivas de Estado caíram no dilema do nacional-popular devido à diversidade cultural própria dos agrupamentos sociais gerados pela colonização europeia.

Identificamos também que as dificuldades em torno das identidades nacionais não são restritas aos países colonizados. Às vezes, de modo mais grave, podem ser encontradas nos territórios políticos dos Estados coloni- 
zadores como Itália e França; onde nasceram o neorrealismo e a Nouvelle Vague como produtos de uma destruição bélica da visão unificada que se tinha acerca dos países europeus ou mesmo da Europa como um todo. Os processos migratórios ou diaspóricos geram ou forçam as relações e as transformações interculturais de grupos ou pessoas. Segundo Shohat e Stam (2006: 38), “[...] a própria Europa é na verdade uma síntese de diversas culturas ocidentais e não-ocidentais”.

O desenvolvimento do colonialismo e do imperialismo foi aos poucos construindo uma Modernidade globalmente compartilhada tanto concernente às suas beneficies quanto aos seus problemas mais cruciais; ao exemplo das dificuldades em se definir as identidades nacionais. Sem embargo, tecnologias como o cinema, a literatura, a música, a televisão não se limitaram a uma difusão técnica e tecnológica, mas também ideológica. Vemos, portanto, que as finalidades políticas do cinema foram comuns a todos os países aos quais chegou principalmente referente ao seu poder acerca das construções das identidades nacionais de Estado ou nacionalpopulares à custa de representações indígenas (Turner 1997; Shohat e Stam 2006; Ortiz 2006; Malafaia 2008; Mattelart et al. 2004). Tal como o índio no cinema norte-americano sendo retratado como bandido e traficante (Nunes 2008).

O paradoxo da Modernidade está, portanto, na emergência de dois fenômenos simultâneos e aparentemente contraditórios. Primeiro, no fato das inter-relações culturais não terem gerado identidades unitárias e monolíticas, mas sim cada vez mais diversidade. Do cruzamento entre culturas colonizadas e colonizadoras não nasceu uma nação híbrida ou mestiça, conceito em que se quis congelar a identidade brasileira. Diferentemente, pipocaram hibridismos diversos e diferentes entre si tanto no interior quanto no exterior dos Estados nacionais. Entretanto, como um segundo fenômeno, as diversidades culturais em termos de agrupamentos, por mais radicais que consigam ser em suas diferenças, nunca compartilharam tantos materiais e ideias em comum, graças à globalização.

Nesse sentido, Ortiz, segundo Matterlat et al. (2004), vem dando ênfase à relação cultural entre o internacional e o popular, em detrimento da antiga união cinemanovista entre o nacional e o popular. De acordo com Vieira (2009: 67), atualmente vivemos um “[...] ressurgimento de identidades culturais [que] se dá paralelamente ao enfraquecimento [...] do nacional e, simultaneamente, ao fortalecimento do local e das organizações da sociedade. O local passa a interagir com o global, criam-se diferentes patamares culturais”. No caso do Brasil ou de qualquer outro país é impossível vislumbrar alguma criação genuinamente nacional. O Cinema Novo, ou mesmo a formação do Estado e da burguesia brasileiros, foram construídos a partir da interação não do país com outros países ao nível institucional e programático dos países. Sempre se tratou de grupos sociais específicos que ao interagirem com práticas e ideologias estrangeiras, investiam esforços em nacionalizá-las enquanto poder político. 
Os fenômenos modernos parecem ontologicamente se constituírem como produtos globalmente compartilhados; ao exemplo da música, do cinema, das artes, da televisão, da fotografia etc.; assim como da miséria, da violência, do tráfico, da pirataria, da polícia, da liberdade sexual, da ascensão feminina, do assalariado, da indústria, do comercio, do consumo, etc.. O próprio nacionalismo de base colonial e imperialista ou anti-colonial e antiimperialista, seja, respectivamente, de ordem política de Estado, burguês ou comunista, seja pela via dos particularistas em busca do nacional a partir do popular, do índio e do negro, ainda é, um fenômeno mundial ou globalizado cujas cinematografias são aparelhos técnicos, tecnológicos e ideológicos de difusão, implementação e manutenção.

Vieira (2009) investiga o nacionalismo como fenômeno compartilhado pelos países da América Latina, comparados aos Europeus, embora cada um estivesse buscando uma identidade nacional própria e originária capaz de diferenciar seu povo em face de seus vizinhos. Para tanto, elege os hinos nacionais como objetos de estudo e descobre, de maneira mais pontual e micrológica, que todos eles compartilham de um mesmo princípio: a morte pela pátria! Uruguai, Paraguai, Argentina, Haiti, Colombia etc. compuseram em seus hinos alguns trechos em que as pessoas do povo e seus governantes são obrigados a declarar que morreriam pela nação em guerras e lutas contra invasores ou colonizadores, tendo como objeto de defesa a nação. Vejamos algumas frases imperativas: a) Liberdade ou com glória morrer; b) Pátria ou morte, venceremos; c) Morrer antes que se ver humilhado; d) Juremos com glória morrer. Basicamente, cada local passou a afirmar sua existência particular e sua identidade imaginada com base em preceitos globais ou, por que não, universalizados.

Contudo, longe de ser uma característica da Modernidade, as interações culturais no espaço de imensos territórios geográficos podem ser identificadas em tempos anteriores aos das Grandes Navegações. Estudiosos apontam para a necessidade de a América Latina ser abordada de um ponto de vista continental, já que "[...] sistemas sociais indígenas existentes às vésperas da conquista não estavam isolados, mas articulados local e regionalmente. Ao que tudo indica; vastas redes comerciais uniam áreas e povos distantes” (Fausto 2005: 9-10). Para Viveiros de Castro (1992; 2011) é possível sugerir a existência de um pan-americanismo ameríndio ou panameríndio ou pan-amazônico pré e pós-colombianos, mas, no sentido das interações entre diferentes, o que obrigaria uma reformulação radical das atuais fronteiras geopolíticas das Américas (Gomes 2012).

A Mídia Indígena, por conseguinte, no mesmo sentido do panamericanismo ou da globalização, como mais um fenômeno da Modernidade ou, agora, da Pós-Modernidade, não tem como exclusividade o Brasil. Contemporaneamente, existem três principais centros -policentros- de produção cinematográfica indígena: “[...] os nativos norte-americanos [Canadá] (inuit, yup’ik), os índios da Bacia Amazônica (nhambiquaras, caiapós) e os aborígenes australianos (warlpiri, pitjanjajari)" (Shohat e Stam 2006: 70). Na visão de alguns estudiosos como Ginsburg e Terence Turner, o fato 
de a Mídia Indígena ser um fenômeno globalizado, em oposição ao originário nativo, faz com que, muitas vezes, suas produções estejam “[...] além da mera afirmação de uma identidade existente para tornar-se 'um meio de criação cultural que refrata e combina elementos das sociedades dominantes e minoritárias” (Shohat e Stam 2006: 71). Evitando hierarquias antropológicas, a Mídia Indígena globalizada não teria como inspiração apenas uma matriz ou um centro de referência, mas sim um modo politrópico de construção que segue a lógica da bricolagem heterárquica ou da antropofagia.

Destaca-se, nesse contexto, um princípio comum entre as produções midiáticas cujos autores são indígenas. Para Costa (2011: 4), os vídeos indígenas “[...] visam confrontar imagens [...] construídas no processo colonial e [...] nos discursos elitistas que conformaram os estados nacionais [...]. Recentemente, as produções audiovisuais indígenas da Bolívia e México foram entendias como parte de uma luta por representações [...] em nível latino-americano". Costa divulga que cineastas, ainda que não indígenas, como o boliviano Sanjinés, engajado no Nuevo Cine Latinoamericano, já levantaram disparidades entre leituras andinas originárias e ocidentais enquanto um problema para a tradição cinematográfica que tenta se impor nos processos do cinema indígena. Para tanto, conjectura outras técnicas de narrativas capazes de contar as histórias a partir de perspectivas que vêm nações no interior de nações; tal como faz figurar o título de um de seus filmes: La Nación Clandestina (1989).

Mas, o Cinema Indígena contemporâneo vai além das transformações provocadas por muitos cineastas não indígenas críticos da Modernidade, acerca das imagens falsamente estereotipadas dos indígenas americanos. A mudança em pauta se dá no campo da produção e não no do produto; mesmo que muitas vezes essa alteração tenha algumas de suas raízes fincadas em iniciativas não indígenas, inclusive com apoios técnicos, tecnológicos e financeiros provenientes dos Estados nacionais ou de empresas mistas, como o caso da Petrobras, no Brasil. Porém, o Cinema Indígena aqui tratado não pode ser identificado, ao menos sem uma cuidadosa reflexão, com a obra do cineasta aborígene, norte-americano, Chris Eyre, em especial com seu principal filme, Smoke Signals (1998). Embora considerado uma produção independente, pois não obedece aos padrões de Hollywood, bem como ser um importante reformulador da imagem do índio no cinema americano, retirando o mesmo da figuração estereotipada do bandido, dirigindo-se às histórias de suas tradições e à crítica da história colonial (Nunes 2008), Eyre não encampa um cinema que apresente o ponto de vista de uma etnia ou mesmo produzido no interior comunitário, pois a direção e a narrativa focam o individual.

Vemos que a situação é complexa até chegar ao que se entende por Mídia ou Cinema Indígena. Comparando o aborígene norte-americano Eyre ao boliviano branco Sanjinés, a prática metodológica deste último está mais próxima do Cinema Indígena ao se comparar com a proposta do primeiro. Embora ambos trabalhem com histórias derivadas tanto do cotidiano indí- 
gena memorial quanto contemporâneo, Sanjinés busca uma prática participativa mediante uma filmagem interativa onde o protagonista é coletivo. Problematizada em filmes brasileiros dos anos 1970, como Congo (1977), de Arthur Omar, a questão principal é ridicularizar a ideia de que um cineasta ou documentarista branco, cientificamente neutro, pela técnica da Voice Over, seja capaz de dizer algo significativo sobre índios e africanos no Brasil. Nesse sentido, a nova pretensão, às vezes difícil de ser alcançada, é a garantia de participação efetiva das pessoas filmadas em todas as fases de produção (Shohat e Stam 2006). Esse tipo de cinema exige que a produção exceda o tempo-espaço do filme, para abranger uma dimensão política e histórica de movimento social que luta por alguma causa e provoca o devir na produção.

O lema de Sanjinés é: “um cinema junto ao povo”. Para tanto, é um dos fundadores do ainda atuante grupo chamado Ukamau, título de um de seus filmes proibidos na Bolívia, produzido em 1966, cujo idioma falado nas gravações é o nativo aymara. Assinando individualmente, mas ao lado da assinatura coletiva do grupo Ukamau, Sanjinés e seus companheiros escreveram uma obra sobre um modo revolucionário de se fazer cinema intitulada “Teoría e práctica de un cine junto al pueblo”, de 1978. Os autores comentam que as imagens em movimento na película não apresentavam ideias pensadas pela mente do cineasta, mas sim imagens recordadas e imaginadas pelo povo. O cinema revolucionário não seria uma criação autoral subjetiva, mas uma construção intersubjetiva. O personagem coletivo força uma transformação na técnica clássica do cinema ocidental de narrar uma história, dividida em cenas cortadas conforme planos ou perspectivas distintas da câmera: plano de conjunto, plano médio e primeiro plano. Dessa negação ocidental nasce o "plano de sequencia integral” sem cortes do movimento ativo de um coletivo durante uma cena. O roteiro e as falas provêm da memória dos atores, personagens reais da história contada por eles próprios no presente (Sanjinés e Ukamau 1978).

Contudo, a experiência de Sanjinés e do Ukamau apresenta como obstáculo a origem da iniciativa e da produção em termos de autoria da proposta: o cineasta não indígena. O Cinema Indígena apresenta sua configuração mais clara no contemporâneo cinema canadense, nas figuras dos seus cineastas aborígenes; apesar de financiados pelo Conselho Nacional de Cinema (NFB) do país, que demonstra ter uma intenção nacionalista em termos do Nacional como abrangência multicultural. O fato é que a NFB foi ao longo dos anos do século XX inserindo os aborígenes na produção fílmica no papel de consultores, pesquisadores, narradores e atores. Sendo que, recentemente implementou uma política sistemática de formar os nativos para atuarem como escritores e diretores do próprio cinema, cujo caráter não é comercial, mediante o Studio One. Do inicio da década de 1970 até final dos 1980 do século passado apenas dois cineastas nativos atuavam no país: primeiramente, a produtora da etnia Abenaki e ativista social Alanis Obomsawin e o produtor da etnia Metis, Gil Cardinal, depois. Suas narrativas e as de outros cineastas recontam a história aborígene antes e depois da formação do Estado canadense, bem como, 
consequentemente, reformulam a história do país (NFB e ONF 2006).

No Canadá merece também destaque a cineasta Manon Barbeau, principal fundadora da instituição Wapikoni, cuja finalidade é formar jovens de periferias e aborígenes na arte do cinema, visando à produção de narrativas autênticas, fora do padrão hegemônico e comercial das grandes empresas de Hollywood. Não se limitando aos povos nativos, a referida cineasta idealizou e colocou em práticas inúmeros projetos voltados às minorias canadenses, incluindo a música, além do cinema, e outros bens culturais. Mas, tratando especificamente da Wapiconi, fundada em 2004, lançou a experiência de um estúdio móvel cuja tarefa é visitar comunidades nativas a fim de oferecer formação cinematográfica integral a jovens comunitários. Além de ter como missão atingir aspectos gerais relativos à cidadania atrelados à questão da identidade cultural, o projeto visou sanar problemas comuns às populações das chamadas Primeiras Nações ou autóctones, tais como altas taxas de suicídio, inserção no mundo do crime, abandono escolar, incorporação de vícios etc.. (Wapikoni 2014).

Embora recentes, as experiências envolvendo povos indígenas, aborígenes, nativos ou denominados de Primeiras Nações vêm sendo difundidas e pulverizadas de maneira cada vez mais veloz e consistente, ampliando seu poder multiplicador no que concerne ao aumento da diversidade de abordagens e metodologias cinematográficas responsáveis, muitas vezes, por motivar distanciamentos em relação às primeiras idealizações invariavelmente derivadas de iniciativas de cineastas ou antropólogos não indígenas. Não obstante, conforme divulgam muitos desses idealizadores, uma das intenções do desenvolvimento das Mídias Indígenas é justamente se afastarem cada vez mais dos modelos ocidentais, que inicialmente serviram de suporte, no sentido de encontrarem princípios e modos próprios de produção. Sendo assim, é impossível não localizar o Cinema Indígena em um contexto contraditório ou mesmo paradoxal nos limites dos nacionalismos modernos em face de propostas de Estados plurinacionais e multiétnicos, já que a diversidade cultural dos países, em especial os colonizados, apresenta ser o principal obstáculo para a consolidação de qualquer projeto nacionalista.

\section{O indígena no cinema brasileiro: de produtos a produtores segundo o projeto “Cineastas Indígenas" da ONG "Vídeo nas Aldeias"}

Um incipiente levantamento realizado por nós, sobre os longasmetragens de ficção produzidos no Brasil no início deste século, aponta para um número significativo de obras que abordam a temática indígena. As sinopses destes filmes indicam uma insistência na elaboração de narrativas que se valem de fórmulas estereotipadas de representação, ainda que com diferenciais de abordagem se comparados a outros momentos da história do cinema brasileiro, a exemplo da lenta inclusão de indígenas atores. 
No plano das representações audiovisuais contemporâneas, é notável a emergência daquilo que Shohat e Stam (2006) chamam, num contexto global, de “mídia indígena”, ou seja, o emprego da tecnologia audiovisual para os propósitos culturais e políticos dos povos nativos. No Brasil, desde a década de 1980, já foram produzidos mais de 70 filmes indígenas, entre médias e curtas-metragens. Esses trabalhos representam historicamente a inauguração da produção dessas narrativas pelos próprios indígenas, que pela primeira vez têm a oportunidade de se constituírem enquanto sujeitos de suas representações cinematográficas e elaborar suas próprias imagens para serem divulgadas no âmbito da sociedade envolvente, bem como nos contextos da diversidade indígena.

Desse modo, esses filmes carregam consigo o potencial de funcionar como contra-narrativas, enquanto um conjunto de representações capaz de confrontar a coleção de imagens estereotipadas produzidas até então nacionalmente, e de trazer as narrativas dos diferentes grupos indígenas para o presente histórico, dando visibilidade às suas culturas e lutas, ao mesmo tempo em que operam como um discurso de reelaboração de suas identidades, passíveis de produção de novos significados.

Considerando os trabalhos sócio-acadêmicos em formação técnica, tecnológica e humana de pessoas, sejam indígenas ou não-indígenas, tanto o projeto "Cineastas Indígenas", promovido pela ONG "Vídeo nas Aldeias”, quanto os projeto propostos pelos autores deste texto, intitulados "Cinema Indígena na Casa de Trânsito Sateré Mawé de Parintins" e "Cinema Indígena e Produção Audiovisual na Casa de Trânsito Sateré Mawé” (ParintinsAmazonas)", realizados com o apoio financeiro e logístico da Pró-Reitoria de Extensão e Interiorização (PROEXTI), Universidade Federal do Amazonas (UFAM); podem ser localizados epistemologicamente no campo dos Estudos Culturais, mais especificamente, como sugerem Shohat e Stam (2006: 445), na área das "auto-representações e das políticas das identidades", responsável por abordar “[...] questões sobre as tensões políticas a respeito de quem fala, quando, como e em nome de quem. As políticas [anticoloniais] das identidades lutam pela 'auto-representação' de comunidades marginalizadas, pelo direito de 'falar por si mesmo'”.

Tratando das representações cinematográficas, Silva (2007) compreende que o cinema implica formas de apropriação relativa do mundo; do ponto de vista de cada grupo social que se coloca como produtor das representações simbólicas em contradição a outros grupos. O cinema é um desses lugares que podem ser denominados de mundo das representações, "[...] em que homens lutam não apenas pelas riquezas materiais, mas também por 'representações coletivas'” (Silva 2007: 124).

Freire (2010: 18) diz que a historiografia nacional imaginando a comunidade nacional, organizou esquecimentos concernentes à imagem dos povos indígenas, segundo quatro equívocos: 1) noção do índio genérico; 2) visão de que as culturas indígenas são atrasadas; 3) imagem dos grupos indígenas como culturas congeladas; 4) ideia de que os índios estão 
encravados no passado, obliterando o fato de que eles integram, em números crescentes e espaços diversos, a sociedade brasileira atual ${ }^{3}$.

Modificadas com reconfigurações de poder, as representações cinematográficas dos povos indígenas que habitam o solo brasileiro trazem um repertório de imagens estereotipadas. Em "Multiculturalismo Tropical" (2008), Stam elenca alguns estereótipos: 1) o "bom selvagem” dos filmes indianistas, cujo estereótipo tem origens literárias; 2) o índio positivista objetificado dos documentários da década de 1920; 3) o índio cômico dos anos 1950; 4) o canibal modernista e tropicalista dos anos 1960; 5) o rebelde alegórico dos anos 1970; 6) o “índio vítima”, dos documentários-denúncia de 1980; 7) o índio auto-representado e ativista da mídia indígena dos anos 1990.

O Centro de Trabalho Indigenista (CTI) e, mais tarde, o projeto "Vídeo nas Aldeias", segundo o ponto de vista do "índio auto-representado e ativista”, foram os idealizadores das oficinas que ao longo dos anos 1980 e 1990 ensinaram a índios técnicas de produção de vídeos. Vincent Carelli e Mari Correa, coordenadores do "Vídeo nas Aldeias”, afirmam que o objetivo do trabalho foi apoiar o fortalecimento das identidades indígenas em um contexto de lenta conquista de direitos ${ }^{4}$. Alinhada a um modelo indigenista, a experiência enfatiza relações interculturais com os índios, opondo-se às políticas paternalistas e nacionalistas, especialmente do período da ditadura.

Ao destacar alguns dos filmes indígenas produzidos nos anos $2000^{5}$, Stam observa que os temas se referem ao "combate à imagem estereotipada do índio, a apresentação dos rituais, o retrato da vida cotidiana, troca de estratégias de luta entre grupos diversos e propostas para a demarcação de terras” (Ibid.: 502). Não obstante, se de um lado os indígenas continuam a servir de inspiração para cineastas na produção de filmes de ficção; do outro, os indígenas começam a dirigir seus próprios filmes. De outro modo, o cinema nacional sempre veiculou imagens caricaturadas e essencialistas dos povos indígenas desde o seu surgimento; entretanto, os modos atuais de produção de narrativas são mais diversos, tornando possível a abertura de espaços paralelos e viabilizando a construção de representações alternativas, alimentando, inclusive, a interculturalidade.

Turner afirma sobre os filmes indígenas que: "Muitas vezes o trabalho vai além da mera afirmação da identidade existente para tornar-se um meio de criação cultural que refrata e combina elementos das sociedades dominantes e minoritárias” (Turner apud Shohat e Stam 2006: 71). Nessa linha, a Organização Não Governamental Vídeo nas Aldeias, em parceria com o Ministério da Cultura do Brasil e a Petrobras, promoveu, nos últimos anos, oficinas e encontros com diferentes grupos indígenas em todo o território brasileiro. Esse trabalho teve como resultado a coleção constituída por cinco DVDs intitulada “Cineastas Indígenas: um outro olhar”, composto por produções cinematográficas dos grupos Kuikuro, Huni Kui, Panará, Xavante e Ashaninka. 
Nos referidos filmes, os próprios indígenas utilizam a linguagem e o recurso audiovisual para contar suas histórias, lutas, mitologias, além de apresentar uma reflexão sobre como o recurso fílmico; que uma vez inserido e apropriado pelas comunidades, pode ser utilizado como fonte de reconhecimento, de valorização, de revitalização, de resignificação, de registro e de difusão culturais, deslocando os processos de produção das representações indígenas do exclusivo controle produtivo -técnico e tecnológico- e do consumo, pela sociedade envolvente, para as mãos dos próprios indígenas.

\section{O projeto de extensão comunitária “Cinema Indígena na Casa de Trânsito Sateré Mawé de Parintins" (Amazonas) e o indígena como espectador}

Partindo das demarcações teóricas acima apresentadas e da proposta do projeto "Cineastas Indígenas”, da ONG Vídeo nas Aldeias, os autores deste texto, professores da Universidade Federal do Amazonas propuseram a realização de um projeto intitulado "Cinema Indígena na Casa de Trânsito Sateré Mawé de Parintins” (Amazonas), que teve como objetivo assistir, junto a alguns membros da etnia Sateré-Mawé, aos filmes produzidos pelos cineastas indígenas, com a finalidade de debater questões das identidades culturais indígenas do Parque Indígena do Xingu, habitado pelas etnias Kuikuro, Panará, Xavante e da Amazônia Brasileira, habitada pelos Huni Kui e Ashaninka. Durante seis meses, através dos filmes e dos debates que sucediam às exibições, refletiu-se sobre formas de valorizar e difundir os conhecimentos e os elementos da cultura Sateré Mawé, trazendo à tona a necessidade de reconhecimento, de registro e de formulações de estratégias, pelo próprio grupo, para dar visibilidade ao papel fundamental de suas representações passadas, atuais e futuras.

Ao promovermos institucionalmente a oportunidade de alguns Sateré-Mawé assistirem aos filmes produzidos por sujeitos de outras etnias, abrir aos mesmos uma perspectiva crítica e contrastante acerca das produções representacionais dos povos indígenas feitas por não-indígenas, cuja ampla circulação por meio de emissoras nacionais de televisão aberta implica o registro de suas fabricações nas memórias indígenas, já permeadas e acostumadas pela ubiquidade das imagens indígenas estereotipadas e veiculadas em revistas, livros didáticos, filmes, novelas, jornais e telejornais.

Esperávamos, por essa via, três desdobramentos pedagógicos: a) oferecer uma possibilidade de ruptura com a ideia de que a produção de filmes é uma arte para poucos ou exclusivamente de não-indígenas; b) causar um estranhamento entre a novidade das produções cinematográficas indígenas e as produções não-indígenas às quais estão acostumados; c) despertar o interesse prático e reflexivo pela produção de "vídeos indígenas" para além da condição de espectadores alienados 
dos meios e modos de produção acerca de suas próprias identidades e culturas.

Concernente a esses três desdobramentos pretendidos, nossa avaliação indicou que os objetivos foram atingidos, principalmente pela ruptura com o caráter exotérico da produção cinematográfica hollywoodiana que vem há anos nos alienando, assim como com o efeito de uma "crítica da imagem eurocêntrica” (Shohat e Stam 2006). Devemos destacar o último desdobramento, pois o mesmo resultou na proposição de um novo projeto, intitulado "Cinema Indígena e Produção Audiovisual na Casa de Trânsito Sateré Mawé”, por uma demanda direta dos participantes Sateré Mawé, no período de julho e agosto de 2011, de produção audiovisual amadora indígena, da parte dos mesmos autores deste trabalho, junto ao grupo de indígenas participantes. Entretanto, antes mesmo que o prazo institucional do projeto "Cinema Indígena na Casa de Trânsito Sateré Mawé de Parintins" se encerrasse, em especial por parte das mães dos jovens e dos próprios jovens residentes na Casa, a demanda pela produção audiovisual se sobrepôs rapidamente à proposta introdutória de inicialmente apenas assistirmos aos vídeos produzidos pelos "Cineastas Indígenas”.

Das seis exibições fílmicas; logo durante a primeira os estudantes adolescentes e suas mães desviaram os olhares para a produção cinematográfica, além da condição de espectadores. O contato midiático com a imagem de outros indígenas na condição de produtores de cinema fez surgir, ao primeiro filme exibido, o desejo de passar da posição de plateia para a de protagonistas atores e produtores. Assistir aos filmes passou a se justificar a partir da função de mediação do desejo pela produção em vez de se perpetuarem como espectadores, ao lado dos manejos técnicos que por ventura pudessem apreender durante o contato com as exibições produzidas por seus "parentes" interétnicos.

Esse desejo despertou um evidente interesse com relação ao cinegrafista -não-indígena- responsável por filmar o desenvolvimento de nosso projeto de exibição de filmes. Logo após a primeira exibição, os jovens indígenas abordaram nosso cinegrafista, de posse de uma filmadora profissional, semelhante àquela que os "Cineastas Indígenas” manipulam nos filmes, perguntando-lhe se seria com a sua filmadora que iriam produzir os filmes Sateré Mawé. A partir desse momento, começamos refletir no interior dos parâmetros prescritos do projeto sobre a possibilidade de construirmos as condições materiais para a produção audiovisual em vez de apenas nos limitarmos, nós e os indígenas, à posição de espectadores, principalmente pela força do interesse dos participantes do projeto.

A solução material encontrada foi operarmos com filmadoras amadoras, as chamadas “câmeras-de-mão" ou "hand-cams”, já que o projeto não possui a aparelhagem profissional, sendo que a filmadora profissional do cinegrafista do projeto era privada ou particular. Mesmo por que, para a manipulação adequada do equipamento profissional necessitaríamos de um tempo que não tínhamos para a capacitação nossa e dos indígenas, 
tempo que foi possibilitado no projeto seguinte, intitulado "Cinema Indígena e Produção Audiovisual na Casa de Trânsito Sateré Mawé”, como destacado há pouco. $\mathrm{O}$ acesso às filmadoras amadoras, como um momento pedagógico de introdução à produção audiovisual cinematográfica, foi satisfatório para os participantes Sateré Mawé do projeto naquele momento.

Ao exemplo dos “Cineastas Indígenas”, os participantes Sateré-Mawé do projeto optaram por filmar uma encenação fictícia de algumas das principais partes do ritual chamado de Ritual da Tucandeira, cuja filmagem compõe nosso relatório do projeto, e outra filmagem do ritual propriamente no contexto de uma comunidade existente no interior da terra indígena, que consiste na iniciação do jovem Sateré-Mawé à vida adulta mediante a recepção de inúmeras ferroadas nas mãos de uma formiga amazônica chamada tucandeira, cuja enzima liberada provoca dor com períodos prolongados de vinte a quatro horas. Tal ritual, embora fundamental para a cultural Sateré Mawé, vem paulatinamente deixando de ser praticado, certamente devido à influência de discursos utilitários, médicos e cristãos, que argumentam no sentido da inutilidade do ritual ou de seu caráter profano e insalubre.

Diante desse movimento, cabe a expressão de Starobinski, segundo Augé (1994: 72): indígenas nos espaços urbanos se movimentam ao modo de uma "marcha de baixo", pois suas tradições "[...] a modernidade não as apaga, mas as coloca em segundo plano”. Elas continuam vivas, mas aparentemente mortas por véus que as deixam urbanamente invisíveis. Quando o urbano identifica um indígena, o apreende como em processo de abandono de suas raízes. É possível destacar um equívoco muito presente no imaginário do sujeito urbano brasileiro a respeito de grupos indígenas na atualidade.

Conforme enfatiza o antropólogo Viveiro de Castro, segundo menção de Araújo (2010): na contemporaneidade, os índios só podem ser vistos de duas formas. Aqueles que "ainda são" e os que "não são mais", noções essas vinculadas a imagens estereotipadas e estanques que continuam, lamentavelmente, a fundamentar o conhecimento sobre o que é ser indígena na atualidade. Ambas as formulações mascaram outros destinos dos chamados processos de assimilação e aculturação, que é, estranhamente, o do fortalecimento de uma identidade cultural. Da mesma forma que as sociedades e estados modernos vêm assimilando diversos conhecimentos indígenas para o seu fortalecimento, como, por exemplo, a indústria farmacêutica (Cunha 2012: 134); alguns povos indígenas vêm assimilando conhecimentos e tecnologias modernas a fim de se fortalecerem.

\section{Projeto “Cinema Indígena e Produção Audiovisual na Casa de Trânsito Sateré Mawé”}

O projeto "Cinema Indígena e Produção Audiovisual na Casa de Trânsito Sateré Mawé”, consistiu no desenvolvimento prático e reflexivo de oficinas relativas às dimensões da produção de um documentário. As 
ações foram divididas em oficinas de: a) roteiro; b) manipulação de câmeras de vídeo; c) cinegrafia; d) edição de vídeos. As oficinas de roteiro trabalharam as dinâmicas de concepção de uma proposta de filme e a elaboração de seu projeto, a partir das discussões em torno dos interesses políticos, culturais, sociais e econômicos que fundamentam o ponto de partida de uma produção cinematográfica; seguidas de ensinamentos em torno da eleição da história, do gênero narrativo, das personagens, dos ambientes ou cenários e do tempo de duração.

Concomitantemente, as oficinas de manipulação de câmera consistiram no ensino-aprendizagem das funções e dos recursos técnicos e tecnológicos das filmadoras, tais como controle de luminosidade, foco, planos, zoom, captação de som etc.. Referente aos exercícios de cinegrafia nos pautamos em atividades práticas de aplicação dos recursos da máquina em situações de filmagem, seguidas de dinâmicas em que assistíamos aos filmes e discutíamos a qualidade das produções, no sentido de inserir melhoras e outras possibilidades. Por último, as oficinas de edição de vídeo implicaram as discussões em torno da montagem ou mesmo conclusão do roteiro. Enfatizamos a relação entre edição e os primeiros momentos da construção do roteiro, principalmente com o foco ou temática central das filmagens, já que esse elemento é responsável por direcionar a seleção de imagens, cenas e vozes.

Derivado de demandas e problemáticas emergidas no seio de uma ação de extensão universitária anterior intitulada "Cinema Indígena na Casa de Trânsito Sateré Mawé de Parintins”, o projeto agora em pauta pode ser caracterizado como a continuação de um processo de inversão da relação entre sujeitos e objetos das produções cinematográficas brasileiras acerca dos indígenas e suas questões de ordem antropológica, política, social, identitária, cultural e econômica. Não obstante, compreendemos que a proposta da formação de Cineastas Indígenas, lançada e executada pela ONG "Vídeo nas Aldeias", junto a diversas etnias localizadas em "território brasileiro", do ponto de vista de seus espectadores, já implica uma difusão e ampliação da abrangência geográfica, social, cultural e política de práticas capazes de subverter a lógica entre sujeito e objeto das produções.

Isso significa, a nosso ver, que a maior parte das produções fílmicas não tocam na possibilidade dessa inversão, aprisionando o espectador em sua condição de consumidor e não-produtor; tendo como exemplo emblemático o cinema hollywoodiano. Para nos expressar por meio de uma analogia, o cinema deve passar pelo mesmo processo vivido pela música popular, em especial o gênero punk rock, a qual possibilita, instiga e autoriza que a população de um modo geral se aproprie de parte dos meios de produção musical a fim de se expressar de modo inovador, mesmo que dentro de limites simples ou mesmo primitivos. Desejamos comunicar com isso, que o atual cinema indígena, produzido por cineastas indígenas, desperta para um ponto de vista acerca do qual, até então, éramos alienados, inconscientes, ignorantes por assim dizer. No campo da alteridade no qual se constrói as identidades, a ação do outro nos instiga e autoriza caminhar pelas mesmas trilhas da inversão da história. 
Nosso trabalho, no contexto do projeto sócio-acadêmico em questão, indica a existência da dimensão ideológica na governabilidade ou estruturação dos comportamentos sociais, culturais, políticos e econômicos. Os impedimentos ou obstáculos para as ações humanas não se restringem ao universo da matéria, mas, por um viés epistemológico e cultural, passamos a ter noção do papel de governo, estruturação, inibição e liberdade, exercido pelo símbolo ideológico nas ações motoras humanas ou, por assim dizer, em algo conhecido como dimensão do trabalho humano, enquanto intervenção e interação entre o humano e a natureza. Nesse sentido, tanto o projeto “Cineastas Indígenas”, quanto nossa ação universitária de extensão junto a alguns Sateré Mawé, na condição de um prolongamento e abrangência do primeiro, levantou uma possibilidade de ação até então ignorada, desconhecida e desautorizada. Os outros índios, no campo da alteridade, retiram-nos de certa alienação.

Vencido esse obstáculo, da passagem que vai do impedimento simbólico ao despertar do desejo para ação material, passamos para o enfrentamento das condições materiais da produção cinematográfica no contexto do projeto, momento no qual se insere parte da efetivação e operacionalização pedagógica, didática, técnica e tecnológica. Importante frisar que embora tivéssemos vivenciado uma primeira ruptura no campo ideológico, o momento de construção das condições materiais da produção cinematográfica revelou a persistência de outros obstáculos e problemáticas de ordem ideológica e simbólica; principalmente se considerarmos no âmbito da vivência técnica e tecnológica da produção as questões levantadas pelos Estudos Culturais acerca da construção das identidades a partir das dinâmicas de conflitos, resistência, negações e afirmações no campo da alteridade.

Ao longo da formação pedagógica, didática, técnica e tecnológica dos participantes do projeto, notamos que as motivações responsáveis por nos levar a uma dinâmica de auto-representação indígena e crítica dos estereótipos etnocêntricos e nacionalistas, não eram as mesmas do ponto de vista dos Sateré-Mawé participantes do projeto. Identificamos essa discrepância motivacional no contexto das oficinas de roteiro, a partir do momento em que a questão dos objetivos, dos interesses e das justificativas vinculados aos desejos de se produzir um filme não explicitaram, nos discursos, questões relativas às críticas, resistências e enfretamentos em torno das temáticas da identidade, da cultura, da política e da economia; tal como prezam as pesquisas e reflexões promovidas pelos Estudos Culturais. As justificativas dos jovens apresentam como fundamento a formação técnica e tecnológica, sendo que o problema dos objetivos para os quais será utilizada tal aprendizagem aparece de modo difuso.

Compreendemos que a questão da valorização e da resistência de uma cultura mediante a apropriação de bases materiais técnicas e tecnológicas não tem como ponto de partida necessário a noção da militância política. No bojo de nossa experiência local, o fascínio pela técnica, pela tecnologia e também pela possibilidade de adquirir o poder epistemológico e institucional 
de manipular as câmeras de vídeo, como um rito de passagem da condição de espectadores a de produtores, marca o questionamento sobre os processos de empoderamento do ponto de vista da vanguarda política. Em termos antropológicos, compreendemos que o outro cumpre uma função direta e arbitrária nos processos de transmissão de comportamentos culturais, de tal modo que nos leva a refletir que a emergência de um comportamento social vem antes de sua consciência política, cultural e econômica.

Doravante, questionamos os participantes sateré-mawé sobre os motivos que os levaram a desejar filmar o Ritual da Tucandeira. Além do silencio, obtivemos como resposta alguns fragmentos em torno de justificativas incompletas, tímidas e incertas pautadas em um desejo de filmar suas realidades comunitárias, para depois assistirem junto aos demais membros da etnia. Intervindo com mais alguns questionamentos, perguntamos se eles gostariam de enfatizar algum aspecto especial do ritual ou mesmo alguma problemática entre a contemporaneidade do rito e suas formas tradicionais, aos moldes das narrativas dos mais velhos, já que alguns elementos e mecanismos foram excluídos, como, por exemplo, a participação das mães no cuidado de seus filhos e o regime alimentar pré e pós-ritual.

Deparando-nos com o silêncio enquanto resposta frequente, a hipótese sobre o interesse técnico e tecnológico anteceder e às vezes se sobrepor aos discursos políticos e culturais de resistência étnica e identitária, decidimos entrevistar alguns sateré-mawé mais velhos e também militantes das causas indígenas de sua etnia, acerca dos possíveis objetivos a serem almejados a partir de produções cinematográficas propriamente indígenas, a fim de contrastarmos com as justificativas e os silêncios dos jovens, do projeto. As respostas militantes se aproximam das discussões teóricas promovidas pelos intelectuais dos Estudos Culturais em torno da inversão das relações entre subalternos e hegemônicos.

Do ponto de vista do militante indígena, identificamos como base das motivações em torno da apropriação de novas práticas e tecnologias a questão da resistência e dos enfrentamentos culturais diante das imposições modernas e nacionais. Sobre os interesses relativos a registrar cinematograficamente o Ritual da Tucandeira, os militantes não titubearam para discursarem sobre a importância de tal ação para a retomada do rito no âmbito de comunidades que não mais o praticam, bem como argumentaram no sentido da memória do povo e o fortalecimento da língua, já que o filme, segundo eles, deveria ser produzido na língua sateré-mawé, inclusive as legendas. Isso demonstra que emergência de uma consciência étnica no campo da alteridade política e cultural não nasce e não está dada de maneira imediata, fácil e pronta ao nível do senso-comum das populações; implicando, exercícios incansáveis de construção dessa consciência. A formação cinematográfica de jovens indígenas passa não apenas como um mecanismo de expressão de conteúdos e formas acabadas, mas também diz respeito a um mecanismo de formação e constituição de identidades étnicas. 


\section{Considerações finais}

Com este artigo buscamos refletir, baseado nos Estudos Culturais acerca de questões identitárias, sobre uma experiência particular com o Cinema Indígena, junto a jovens da etnia Sateré-Mawé, em face de alguns aspectos e contextos históricos, políticos e culturais da produção cinematográfica na Europa, nas Américas e no Brasil. Basicamente, pudemos acompanhar que o Cinema Indígena não é exclusividade brasileira, pois tal fenômeno vem sendo crescente e sistematizado em outras partes do globo, especialmente no Canadá, com os trabalhos apoiados pela NBF e pela Wapikoni, bem como apresenta certas raízes em movimentos políticosculturais que o precederam ou que são contemporaneamente mais abrangentes, a exemplo do Cinema Novo e mesmo dos Estudos Culturais, respectivamente. No Brasil, demos destaque ao projeto "Cineastas Indígenas" da ONG pernambucana "Vídeo nas Aldeias", bem como ao trabalho específico desenvolvido pelos presentes autores.

Nesse sentido, pudemos notar que concernente ao contexto global que envolve o Cinema Indígena, por um lado, tal fenômeno vem sendo produzido no fluxo de continuidades e rupturas da história dos processos colonialistas, descolonizadores e/ou pós-coloniais do Ocidente, assim como, por conseguinte, na história do cinema mundial, esse último, enquanto um dado de uma história ocidental mais estrutural, implicando uma relação cíclica, interativa, crescente e transformativa. Por outro lado, o Cinema Indígena se apresenta como mais um mecanismo -depois dos "descobrimentos", da escravidão, da catequização, do trabalho, da integração- de inserção dos povos indígenas na chamada história mundial, que pode ser entendida, grosso modo, como um grande acervo enciclopédico de acontecimentos e movimentos correlacionados por sistemas políticos e econômicos abrangentes ou pretensamente hegemônicos, como é o caso da colonização e do imperialismo capitalista e comunista.

Pensamos, dessa forma, que o Cinema Indígena e as Mídias Indígenas fazem parte de um processo de assimilação que há anos os indivíduos e povos indígenas vêm realizando em relação a técnicas, tecnologias e ideologias ocidentais e brancas. Entretanto, parece haver no caso em pauta uma ruptura histórica e política nesse caminho, na medida em que a incorporação das Novas Tecnologias vem possibilitando aos indígenas participações mais ativas no devir histórico da humanidade e, por que não, da natureza. E essa posição ativa vem implicando dados que historicamente foram negados os poderes às Nações Primeiras: a produção, a difusão e a assimilação de suas imagens ou representações, já que essas foram monopolizadas pelos agentes da colonização e o do imperialismo.

Estudamos os modos falsos e estereotipados como os colonizadores apresentaram ao mundo a figura do índio, do aborígene ou do nativo; mediante suas técnicas e tecnologias cinematografia. Conhecemos, portanto, alguns dos princípios e métodos utilizados para configurar os estereótipos indígenas em termos de interesses políticos e econômicos em relação à 
identidade nacional. Para tanto, devemos lembrar que o colonialismo e o imperialismo político e econômico atingiram um estágio nacionalista no século XX, o que gerou nos Estados nacionais e em sua burguesia a necessidade de apresentar certas imagens acerca de indígenas de acordo com um modelo de unificação identitária atrelada à ideia de país-nação. Isso, em detrimento de toda diversidade nativa existente nos territórios.

Por essa via, pensamos que o Cinema Indígena vem configurando uma chance de os povos nativos reconstruírem suas imagens tanto em relação à sua própria história passada em termos de memórias orais e mitos, assim como a possibilidades de projetarem imagens futuras acerca do que deverá ou será o índio como contraponto da hipótese de sua extinção ou a imagem de sua ausência demográfica ou desaparecimento por processos de extermínio, genocídio ou miscigenação. Sem embargo, quem sabe a ideia da miscigenação seja o mecanismo mais eficaz de promoção da extinção indígena, pois, ao menos no Brasil, os brasileiros urbanos foram aos poucos convencidos de que a existência indígena só pode estar associada a uma representação naturalista do passado já encoberto por imagens ocidentais.

A imagem primitiva do índio justificaria, essencialmente, o argumento de que o índio que se apresenta com alguns signos modernos, como a roupa e a câmera de filmagem; não pode ser considerado índio original ou de verdade; já que apresenta traços de mistura. De tal modo, não podemos perder de vista que a hipótese da extinção pela via da miscigenação justificaria expulsar as populações indígenas de suas terras demarcadas com base no argumento de que não mais são índios, mas sim, mestiços, como ribeirinhos e outros pequenos agricultores, já que vivem de maneira semelhante aos brancos; tendo, portanto, que serem inseridos no sistema capitalista de direito à terra. Os cinemas nacionais ou nacionalistas projetaram imagens indígenas como se ainda tivessem que viver no passado como uma estratégia de justificar aos índios contemporâneos, mestiços, a perda de direitos (Cunha 2012).

O Cinema Indígena começa a promover uma torção na história colonial, pois suas produções apresentam a identidade indígena vinculada a outros fatores que não as características culturais mais aparentes comparadas ao passado. Por mais paradoxal que possa parecer, embora se trate de uma tecnologia assimilada, o cinema abre um horizonte de representações diversas do índio com base em seus próprios pontos de vista, sem que deles sejam cobrados aspectos essenciais de suas tradições, pois agora o índio vem se apresentando à história de uma perspectiva existencialista em oposição ao lugar essencialista e naturalista até então imposto a ele. Em termos pósestruturais, o cinema conduz os indígenas por caminhos, pontos e posições nunca antes experimentados e, por isso, vêm reconfigurando a sociedade como um todo, já que transformam, com isso, as relações políticas entre as forças sociais, culturais e econômicas; apesar das primeiras iniciativas não indígenas.

Pensando sobre nossa experiência junto aos jovens Sateré-Mawé, há um ponto de vista a ser destacado sobre esse processo de acesso ao 
desejo pela produção cinematográfica e pela sua realização material: o interesse dos jovens em filmarem o ritual da Tucandeira diante da desvalorização urbana do indígena no interior da sociedade envolvente ou nacional. Por que eles não se inclinaram a reproduzirem novelas televisivas ou algum filme hollywoodiano? Por que diante da desvalorização dos indígenas eles se motivaram a investirem em uma produção fílmica acerca de um dos traços principais da etnia?

Em outras palavras, será que foram os "Cineastas Indígenas" e a sugestão de nosso projeto que produziram em seus “parentes” Sateré-Mawé o desejo de serem "Cineastas Indígenas" em vez de desejarem ser "Cineastas Hollywoodianos”? Ou teria ali sido despertada a alma ancestral e essencial Sateré-Mawé independentemente dos filmes exibidos? Optamos pela hipótese existencialista de que o desejo de voltar um olhar cinematográfico à própria cultura, só foi possível porque seus "parentes” de outras etnias estavam como protogonistas da produção. Essa é a função política no sentido "pós-estrutural” de entidades como a ONG "Vídeo nas Aldeias" e seu projeto "Cineastas Indígenas", bem como os projetos objetos deste texto, "Cinema Indígena na Casa de Trânsito Sateré-Mawé de Parintins" e "Cinema Indígena e Produção Audiovisual na Casa de Trânsito Sateré-Mawé”.

É possível que se fossem exibidos outras modalidades e gêneros cinematográficos, o desejo se manifestaria de outro modo? Passamos a considerar que não adianta esperarmos que a tradição resista à Modernidade apenas pela ação prístina da tradição ou da ancestralidade. É necessário que os sujeitos do presente evoquem o passado e seus mortos pelas vias materiais disponíveis, principalmente mediante um materialismo simbólico e social promovido pelas ações do outro. Caso haja o desejo da preservação e resistência dos modos não-modernos de vida, é necessário que eles sejam praticados de modo explícito a fim de que invada e afete todos aqueles sujeitos em seus campos de ação.

É fracassada a ideia de que o não-indígena ou o próprio indígena venha se sensibilizar com as questões políticas e econômicas apenas pela ilusão de alguma identificação ancestral genética e espiritual que por ventura esteja em seu interior inconsciente em estado de latência pronto para despertar por vontade própria ou por meio de algum sonho fortuito e inesperado. É necessário um agente político para que os sujeitos produzam seus sonhos no campo da cultura e de uma tradição. Nesse sentido, nossa primeira opinião sobre os motivos políticos de militância e de vanguarda que estariam levando os jovens sateré mawé se interessarem pela produção cinematográfica foi um equívoco.

Enquanto o campo das ubiquidades visuais for ocupado por imagens modernas e brancas, os indígenas e os não-indígenas continuarão a desejar as coisas da Modernidade em oposição às matrizes técnicas e tecnológicas ameríndias e africanas então envergonhadas. Não mais podemos acompanhar uma privação dos indígenas e dos não-indígenas menos favorecidos, trabalhadores e marginais em relação aos meios de produção dos 
sistemas maquínicos modernos e capitalistas responsáveis por representar e subjetivar essas mesmas pessoas sob pontos de vistas que não lhes são próprios; condenando-os a um passado imaginado de modo expropriado.

É especificamente nesse ponto das questões culturais e identitárias que nossos projetos de extensão, intitulados "Cinema Indígena na Casa de Trânsito Sateré Mawé de Parintins” e "Cinema Indígena e Produção Audiovisual na Casa de Trânsito Sateré Mawé”, buscaram agir no sentido de refletir sobre a necessidade de valorização e registro de seus próprios saberes e cultura, quanto compartilhar um pouco desses conhecimentos com os membros do projeto, no sentido de trazer à tona o desejo de reconhecimento, de registro e de formulações de estratégias, pelo próprio grupo, mediante a inversão de papeis, para dar visibilidade ao papel fundamental de suas representações passadas, atuais e futuras no contexto da cidade, motivados a partir das produções cinematográficas de autoria de cineastas indígenas de diversas etnias viventes, de modo a promover um campo de interações profícuas e ampliadas no sentido de sua difusão e impacto na vida social indígena e não-indígena. 


\section{Notas}

${ }^{1}$ Este artigo é uma versão revisada e ampliada de um trabalho publicado no Anais do III Seminário de Estudos Culturais, Identidades e Relações Interétnicas (SECIRI), promovido pelo Grupo de Estudos Culturais, Identidades e Relações Interétnicas, realizado na Universidade Federal de Sergipe no ano de 2013. O seguinte link pode ser consultado: http://gerts.com.br/seciri/v1/?page_id=68

${ }^{2}$ No presente texto, as palavras "indígena”, “aborígene” e "nativo”, bem como, com menor freqüência, os termos "autóctones”, "povos originários” e "nações primeiras”, estão sendo utilizados como sinônimos. Embora seja recomendável a opção pela aplicação de apenas um dos termos no sentido de unificar a terminologia exposta, os autores escolheram trabalhar com uma pluralidade de designações para o conceito de "indígena", termo mais central este trabalho. Isso se deve ao fato de a literatura estudada apresentar, em seu conjunto, essa pluralidade terminológica, já que as publicações consultadas têm diversas origens epistemológicas e lingüísticas. Assim, de modo resumido podemos afirmar que a palavra "indígena" é comum no Brasil; "autóctones”, entre ingleses e norte-americanos; "aborígenes”, pelos anglo-saxônicos que estudaram os nativos da Oceania. Na América Latina vem se fortalecendo a política e o direito de chamar os indígenas de Povos Originários e no Canadá de Primeiras Nações, ambos os casos nos sentido de enfatizar a presença de outras etnias no continente antes da chegada dos europeus.

${ }^{3}$ De acordo com o critério de autodeclaração por situação de domicílio, o censo 2010 do Instituto Brasileiro de Geografia e Estatística (IBGE) indica a existência de 817.963 indígenas, o que corresponde a 0,4\% da população brasileira (IBGE 2012). Esse total divide-se em aproximadamente 230 etnias, segundo Garnelo (2012).

4 Informação do site Vídeo nas Aldeias: http://www.videonasaldeias.org.br (acessado em 30 de dezembro de 2013).

${ }^{5}$ Wai'A Rini (O poder do sonho), 2001; Vamos à luta, 2002; e Daritire (Aprendiz de Curador), 2000, do diretor xavante Divino Tserewahu, são alguns exemplos. 


\section{Bibliografía}

Almeida, Maria Regina Celestino de (2010), Os índios na história do Brasil, Editora FGV, Rio de Janeiro, (Coleção FGV de bolso, série História)

Araújo, Ana Carvalho Ziller de (2010), “O índio está acabando?”, em Ana Carvalho Ziller de Araújo (comp.), Cineastas indígenas, um outro olhar: guia para professores e alunos, Vídeo nas Aldeias, Olinda, PE, pp.15-16.

Augé, Marc (1994), Não-lugares: introdução a uma antropologia da supermodernidade, $9^{a}$ ed,, Tradução de Maria Lúcia Pereira, Papirus, Campinas, SP.

Autran Arthur (2003), Alex Viany: crítico e historiador, Perspectiva, São Paulo; Petrobrás, Rio de Janeiro, (Debates; 290)

Carvalho, Maria do Socorro (2006), “Cinema Novo brasileiro”, em Fernando Mascarello (comp.), História do cinema mundial, Papirus, Campinas, SP, (Coleção Campo Imagético) pp.289-310.

Costa, Warley (2011), “Acerca de produções audiovisuais indígenas: reflexões para uma abordagem”, em Anais, II Seminário de Pesquisa da Faculdade de Ciências Sociais, Universidade Federal de Goiás, p. 1-7.

Cunha, Edgard (2000), Cinema e imaginação: a imagem do índio no cinema brasileiro dos anos 70, Dissertação, Programa de Pós-graduação em Antropologia Social, Universidade de São Paulo.

Cunha, Manuela Carneiro da (2012), Índios no Brasil: história, direitos e cidadania, Claro Enigma, São Paulo, (Coleção Agenda Brasileira)

Fabris, Mariarosaria (2006), “Neorrealismo italiano”, em Fernando Mascarello (comp.), História do cinema mundial, Papirus, Campinas, (Coleção Campo Imagético), pp.191-220.

Fausto, Carlos (2005), Os índios antes do Brasil, $3^{\mathrm{a}}$ ed., Jorge Zahar Ed., Rio de Janeiro, (Descobrindo o Brasil)

Freire, José Ribamar Bessa (2010), “A herança cultural indígena, ou cinco ideias equivocadas sobre os índios”, em Ana Carvalho Ziller de Araújo (comp.), Cineastas indígenas: um outro olhar: guia para professores $e$ alunos. Vídeo nas Aldeias, Olinda, PE, pp.17-33.

Gomes, Denise Maria Cavalcante (2012), “O perspectivismo ameríndio e a ideia de uma estética americana”, em Bol. Mus. Para Emílio Goeldi. Cienc. Hum., Brasil, Vol. 7, º1, pp. 133-159. 
Malafaia, Wolney Vianna (2008), “O mal-estar na modernidade: o Cinema Novo diante da modernização autoritária (1964-1984)”, em Jorge Nóva et al. (comps.), Cinema-história: teoria e representações sociais no cinema, $2^{a}$ ed., Apicuri, Rio de Janeiro, pp.201-217.

Matterlart, Armand (2004), Introdução aos Estudos Culturais, Parábola Editorial, São Paulo, (Na ponta da língua; 7)

National Filme Bord et al. (2006), Vozes visuais: um festival de cinema e vídeo aborígene canadense. Canadá.

Nune, Jorge Eduardo Radburn (2008), A reabilitação da imagem dos índios no cinema americano: desde 1970 até hoje, Dissertação de Mestrado em Cinema e Literatura Norte-Americana, Universidade de Lisboa, Departamento de Estudos Anglísticos.

Ortis, Renato (2006), Cultura brasileira e identidade nacional. Brasiliense, São Paulo.

Sanjinés, Jorge; Ukamau, Grupo (1978), Teoría e práctica de un cine junto al Pueblo, Siglo Veintiuno Editores.

Shoat, Ella; Stam, Robert (2006), Crítica da imagem eurocêntrica: multiculturalismo e representação, Cosac Naif, São Paulo.

Silva, S. T. P. da (2007), "História, documentário e exclusão social”, em J. D. Barros (comp.), Cinema-história: ensaios sobre a relação entre cinema e história, Laboratório de estudos Sobre Sociedades e Culturas, Rio de Janeiro, pp. 119-162.

Stam, Robert (2008), Multiculturalismo Tropical: uma história comparativa da raça na cultura e no cinema brasileiro, Edusp, São Paulo.

Idem (2003), Introdução à teoria do cinema, Papirus, São Paulo.

Turner, Graeme (1997), Cinema como prática social, Summus, São Paulo.

Vieira, Liszt (2009), “Morrer pela pátria? Notas sobre identidade nacional e globalização”, em Liszt Vieira (comp.), Identidade e globalização: impasses e perspectivas da identidade e da diversidade cultural, Record, Rio de Janeiro, pp.61-86.

Viveiros de Castro, Eduardo (1992), “O campo na selva, visto da praia, Brasil”, em Estudos Históricos, Vol. 10, pp. 170-199.

Idem (2011), “O medo dos outros”, em Revista de Antropologia USP, Brasil, Vol. 54, N², pp. 885-917. 
Polis, Revista Latinoamericana, Volumen 13, $N^{\circ}$ 38, 2014

Wapikoni, Qui sommes-nous? Disponível em: http://www.wapikoni.ca/apropos/qui-sommes-nous. Acessado em: 10 de março de 2014.

Recibido: 15.05.2014

Aceptado: 15.07.2014 